\title{
How to Argue about Health Care
}

\author{
Don Herzog, Ph.D.*
}

Despite the aggressive title of this article, my goals are modest. I begin by explaining briefly what should at any rate be obvious: that health care policies inescapably raise moral and political difficulties, difficulties that no technical fix could resolve. I move on to puzzle over the connections between some of the more abstract issues of moral and political theory and medical policy: here I urge that we develop a more sustained taste for exploring the moral conflicts embedded in our current practices. Finally, I suggest a strategy for making nitty-gritty facts-from the concrete world of third-party payment, expensive technology, and the rest-do theoretically innovative work for us, and use that strategy to sketch an argument against the market model of health care provision.

\section{COULD MEDICAL POLICY EVER BE PURELY TECHNICAL?}

That issues of medical care seem at least to raise profound moral and political questions is undeniable. Is it fair - the fact is undeniable, even if the metrics are controversial-that rich people get better medical care than poor people? Is abortion justifiable? And if it is, should Medicaid fund abortions for the poor on demand? Should we sink more money than we do into mundane preventive care, or concentrate our resources

*Assistant Professor, Department of Political Science, College of Literature, Science, and the Arts, University of Michigan, Ann Arbor, Mich. 
on spectacular efforts to save people with highly visible and moving problems? If adding 16 cents to the price of a pack of cigarettes would induce 3.5 million people to stop smoking, thus preventing 850,000 early deaths (Harvard University 1985), should the government slap on some more tax? Should the medical market, or what there is left of one, be left to its own devices? Or is there a case for piecemeal or systematic government intervention? Should cancer victims be allowed to purchase Laetrile? If Dr. Nagel finds himself at the scene of an accident, able to save either 20-year-old affable Jim or 60-year-old brilliant Sarah, but not both, what should he do? And how should we react when we notice that, thanks to scarcity, our policy decisions inevitably present the same issues of triage?

However undeniable it seems to many of us that these questions are inescapably moral and political, some are inclined to cast them as technical dilemmas. (By technical dilemma, I mean a question of what means best realizes a given end.) Abusively branding such people technocrats will not make them disappear. Nor for that matter will anything else: the technocrats we will have with us always. But it is worth reiterating the arguments against the availability of any technical fix, and it is helpful to notice why so many find technical fixes alluring. Let me consider four approaches to technical fixes: economic analysis, utilitarianism, scientific authority, and piecemeal social engineering.

If we are wondering how to allocate federal money, or for that matter if we run a private hospital and are wondering what our budget should look like, anyone reasonably conversant with introductory economics may suggest that we shift our funds until we have equalized the value of the marginal dollar spent in each arena. The proposal seems the quintessence of rationality, until we ask what counts as value, and how we are to measure it. If we need to know whether we should alleviate the suffering of a terminal cancer patient or spend the same money on increasing the survival odds of a badly deformed infant, the economist's advice is singularly unhelpful. We still need a standard of value, and as soon as someone suggests that the infant's survival is more important, we are back at square one, with a nontechnical question.

Utilitarianism might be thought helpful. A utilitarian, after all, has a substantive account of value: we should maximize happiness across the population. (Here I ignore the surprising variety of ways of unpacking that principle: Is it mean or total happiness? Does the relevant population include fetuses, or nonhuman animals? Is happiness a pleasurable mental state or preference satisfaction? Which should maximize happiness-our rules and social practices, or each and every act? That there is such a surprising variety suggests that even debates among utilitarians themselves cannot be purely technical.) The utilitarian standard, if accepted, 
would transform not just questions of health policy, but all political questions, into technical ones. In every case we should simply choose whatever alternative maximizes happiness. And we can readily imagine a bright young army of bureaucratic happiness consultants, trained in our nation's public policy institutes to perform the relevant calculations.

But we have no good reason to adopt utilitarianism. (See Herzog 1985, chapter 3, for discussion of the putative justifications for utilitarianism.) Many other decision rules could transform moral and political questions into technical ones. For instance, we could do whatever was proposed first, or we could throw dice to choose the winning policy. And despite its unmistakable historical prestige, utilitarianism has been given no better justification than either of those zany possibilities.

At the same time, utilitarianism is notoriously inept at handling issues of life and death, the very issues central to health policy. Offhand it seems as though someone out to maximize total happiness should insist on a population explosion, at least until the marginal birth led to a decrease in total expected happiness thanks to overcrowding. And it seems as though someone out to maximize average happiness should want to play ten little Indians, systematically bumping off the least happy individuals in the population. Finally, it seems that a utilitarian should think that a painless death, or a death that would not change the greatest happiness score, is morally indifferent. More important, utilitarians simply misunderstand the particular agonies of health policy decisions. Our worries about what to do with a suffering parent are hardly exhausted by questions about happiness; they are so poignant because of our considerable regard for autonomy, for trying to be responsive to the freedom and self-respect of that bedridden individual. It is not just that the patient suffers; it is that the patient is helpless. In fact, we now care about much else besides maximizing happiness; utilitarians have given us no good reason to drop our other concerns.

Yet another approach to finding a technical fix is provided by the appeal to scientific authority. The world of medicine-I insist on the significance of this point later-is for most of us a mysterious world, where briskly self-assured experts dispose of our fates without bothering to sketch rationales, or by sketching rationales we are simply incapable of following in any depth. No doubt such authority is readily exploited: we all have. seen the callous doctor who speaks in polysyllables simply to fend off anxious patients and their demanding relatives. Still, this is a context where some authority is here to stay, and for goor reason. We do not all go to medical school, or read up on advanced microbiology in our spare time, and so it makes sense for us to defer to medical experts. Some then will want to expand the bounds of medical expertise, to 
suggest that doctors have special insight into what strike the rest of us as moral and political dilemmas. Doctors themselves are often ready to assure us that they should be left to decide whether a baby with spina bifida should be kept alive. Ronald Reagan has made a similar move in urging that scientists have shown that the fetus is a person, and so abortion is wrong. But medical expertise cannot go this far. Being better acquainted with the facts of the matter can make doctors more discerning judges, but when they decide what to do with a badly deformed baby, or whether a fetus is a person, their medical expertise does not do the job. Spina bifida and abortion both raise questions about the boundaries of the concept of personhood, about how beings not obviously qualifying as persons ought to be treated. And personhood is a moral, political, and legal concept, not a scientific one. To call some being a person is to say it is entitled to certain sorts of respect. Once we decide what criteria are relevant to qualifying as a person, scientists can help establish whether some being meets the criteria, but they cannot claim to have expertise on the right criteria. To succumb to scientific authority here is to be mystified-or, perhaps, devious.

One last way of seeking a technical fix here is provided by some versions of piecemeal social engineering, or incrementalism. Suppose we eschew all attempts to hammer out moral and political principles to illuminate health policy. Suppose instead we note that there are certain pressing problems that demand solutions. Medicaid leaves many or most poor people uncovered; the unemployed can lose their health insurance benefits and not qualify for any replacement; water tables in some areas are increasingly toxic. Given such problems, one might think only a philosophical skeptic could doubt that we need to do something. We need to frame the most effective solutions we can. And, the incrementalist will add, surely we can talk about problems and solutions without bothering with lofty or metaphysical talk about justice, or desert, or property rights.

I am myself fond of the problem-solution framework. But nothing is gained, and much is lost, by trying to purge all moral and political dimensions from our descriptions of problems and solutions. That one can be poor and not have even rudimentary health care in this country is a problem partly because it so greatly disadvantages the poor, because it seems unfair, and so on. That water tables are toxic is a problem partly because the individuals affected are not responsible for the toxicity, because they are the unwilling victims of corporate decisions, and so on. Solutions, meanwhile, are not only more or less effective. They are more or less just, more or less intrusive on liberty, and so on. We could, I suppose, learn to purge any "offensive" moral and political concepts from our accounts of problems and solutions, but why should we? Doing so 
would impoverish our understanding of the world. Just as the utilitarian gives us no good reason to stop caring about things besides the greatest happiness, so the technocratic incrementalist gives us no good reason to limit our accounts of problems and solutions.

It is also worth noting that many too readily applaud the genius of incrementalism as a rational way to make policy. You do not have to be Edmund Burke to be skeptical of our ability to remake the social and political world from scratch in any intelligent way. Piecemeal social engineering thus becomes instantly attractive: if we fiddle at the margins instead of redesigning everything at once, we can tell which measures improve things and which worsen them. We can also compromise on hotly fought issues. The rejoinders should be obvious. First, how rational could piecemeal social engineering be when we tinker with everything at once in a constantly shifting environment? What hope is there for estimating with any shred of reliability what is helping and what is hurting? Second, piecemeal social engineering constantly gives rise to blatantly irrational policy gaps. There is no good rationale for extending federal largesse to those needing renal dialysis but withholding it from those needing other expensive and ongoing therapies. Instead, Congress, moved by a parade of needy witnesses, happened to plug that particular gap. Third, compromise may often give us the worst of both worlds; or, to put it another way, compromise may be the art of making everyone unhappy.

So where do we stand? It is not just that health policy seems to present moral and political dilemmas, rather than only technical ones. It really does present such dilemmas. We could, if we liked, refuse to pay attention to them. We could steep ourselves in economic analysis or utilitarianism; we could defer to the decisions of scientists or bureaucrats. Doing so, though, would be a bit of bad faith or self-deception, a sign not just of psychological evasion but of political irresponsibility. Given the pressing place moral and political questions have in our lives, evading them shortchanges others as well as ourselves.

Why then is the evasion so tempting? Why have so very many, in such very different ways, sought to find technical fixes to policy problems? A full answer would be extraordinarily complex, but two points are worth noting. We want democratic debate to be as full an airing as possible of our problems and tentative solutions. Democracy, I would suggest, is justifiable not because of any alleged right of the majority to rule, but because of the central emphasis it places on debate and deliberation. If democracy is government by discussion, it should be a more rational political system. Now, there are contexts in which democratic debate should not be utterly full and public: foreign policy is a classic 
example. And perhaps sometimes issues should be underplayed because they lend themselves to strident and explosive rhetoric, and we want to keep ongoing debates in other areas moving along productively. This justification is more problematic, and lends itself all too readily to serving as a pretext for a decidedly uglier cause: sometimes debate will be curtailed lest it serve the interests of the less powerful.

Some of our desire to transform questions of health policy into technical issues arises in just this way. Many suspect that the best arguments we can articulate point toward making the American health care delivery system a good deal more egalitarian than it now is. If that is so, doctors may fear losing six-figure incomes, and the middle classes may fear increased taxation. Egalitarianism need not mean either of those things: we would need to hear more than the mere mention of equality to know what is at stake. But from a narrowly self-interested point of view, democratic debate may seem threatening.

It would however be wrong, not just uncharitable, to suggest that everyone who does not want to explore the moral and political issues lurking in health policy must be an unprincipled scoundrel out to protect his or her own interests. The tenor and substance of today's public rhetoric plays a role. We have learned to celebrate individual initiative-the free individual who makes his or her own way, asking no favors and earning his or her keep. We have learned too to celebrate markets as social mechanisms that generate optimal allocations given reigning preferences and holdings. Worries about social institutions and justice simply do not fit comfortably into that public rhetoric. (To which one might add, so much the worse for today's public rhetoric.) To recur to the means-end distinction, we have become acutely conscious, thanks partly to our fabled budget deficits, that we have a scarcity of resources for realizing our ends. Yet, not only our means are scarce. The more serious, if less often noticed, scarcity relevant to policy concerns is a scarcity of agreement on ends. We simply disagree, in pointed and protracted ways, about what we ought to be striving for.

\section{SOME COMPETING STRATEGIES IN MORAL AND POLITICAL THEORY}

Once we surrender all hopes of turning health policy into a technical field, we need to find a way of arguing about what we ought to be striving for. It might seem sensible first to hammer out a general theory of justice and then apply it to the case. I want to suggest that that strategy is misguided; here I briefly examine the recent powerful theories of John Rawls, Robert Nozick, and Michael Walzer. 
We can start by noting that we do not begin with a moral blank slate. Some may be clear and firm, others murkier and more conditional, but we already hold views about these issues. We may believe for instance that no human being should be without a "decent minimum" of health care, or that the government should restrict itself to informing us of the risks of cigarette smoking, but not paternalistically try to prevent us from smoking. Moral and political theorists sometimes call such views our moral intuitions, without thereby committing themselves to any belief that they are observational reports on some realm of moral facts (Prichard 1971; Ross 1973). It is, putting it mildly, difficult to imagine what sort of creatures moral facts might be. (See Mackie 1977, chapter 1, for a critique.)

What role should those intuitions play in our arguments? Two strategies have struck many as attractive, but I want to reject both of them. The first is to say that our intuitions must be ultimately decisive; they are, one might think, all we have. Such a view may motivate Judith Jarvis Thomson's intriguing defense of abortion (Thomson 1971). Thomson produces clever analogies to illuminate the abortion puzzle. She asks, for instance, what one should do if a superb violinist were kidnapped by the Society of Music Lovers and strapped into some hospital apparatus to be kept alive, and suggests that if one is allowed to pull the plug and get up, women have no obligation to keep their fetuses alive. But in the end it is the force of our intuitions that does the argumentative work. The second strategy is to reject our intuitions, to insist that we learn to get along without them; they are, one might think, nothing but the product of our upbringing, so we have no reason to take them as particularly rational or defensible. Such a view clearly motivates R. M. Hare's ethical theory, and leads him to complain that Thomson "simply parades [her] examples before us and asks what we would say about them" (Hare 1975). Hare wants the bare logic of the moral concepts to be the grounds of moral and political theory.

It would be foolish to claim that we have to either draw on our moral intuitions or try to build a systematic theory. We can try to work up our intuitions into a systematic theory, and in a very abstract way we can take that as a description of what Rawls, Nozick, and Walzer are up to, for all the otherwise interesting differences in their accounts. Let me offer a summary sketch of each theorist's views.

Rawls wants to arrive at principles of justice for regulating what he calls the basic structure of society, or those social institutions that play an important role in allocating life chances (Rawls 1971). His justificatory strategy for defending his principles is complex: he wants to claim that rational agents in a fair position would choose them, that they match our considered judgments and extend them in an acceptable way, and that 
they could serve as a shared public understanding in a stable society. These three criteria all condition each other: we may juggle the description of the fair position to accommodate our intuitions about acceptable principles, for instance, or we may alter our account of what principles could serve as a shared public understanding once we see the derivation of those principles from the fair position. Critics have seen here an illicit attempt to run together competing arguments, and so have suggested that Rawls is simply rigging his theory of justice (Wolff 1977, chapter 16). Rawls's response, I take it, would be that political theory is all about revising judgments in different realms to make them more coherent. "Justification," as he puts it, "is a matter of the mutual support of many considerations, of everything fitting together into one coherent view" (Rawls 1971, p. 579).

What principles emerge from this complex theoretical strategy? Briefly, Rawls defends two principles of justice. The first, which has priority over the second, says that: "Each person is to have an equal right to the most extensive total system of equal basic liberties compatible with a similar system of liberty for all." The second says that: "Social and economic inequalities are to be arranged so that they are both: (a) to the greatest benefit of the least advantaged, consistent with the just savings principle, and (b) attached to offices and positions open to all under conditions of fair equality of opportunity" (Rawls 1971, p. 302).

Offering any full account of the meaning of these principles would carry us well into the intricacies of Rawls's theory. Here we can ask this: What implications do these principles have for matters of health policy? Since Rawls wants principles of justice for the basic structure of society, it would be a mistake to seek in his views any guidance for what Norman Daniels calls micro questions of health policy, questions on what individual actors should do in problematic settings. But, as Daniels notes in his thoughtful attempt to extend Rawls, it is surprisingly unclear what the upshot of Rawls's theory is even for macro questions of health policy (Daniels 1985, pp. 42-48; Daniels makes an especially interesting claim about the formalism of Rawls's theory in note 2, p. 44). Probably the best bet is to exploit Rawls's connecting the priority of liberty with self-respect, and argue that health care plays a crucial role in assuring the self-respect of individuals. This would entitle all citizens to equal health care, or perhaps a decent minimum; certainly it seems in the spirit of Rawls's theory to think that health care is not the sort of thing that should be left to the vagaries of the market. It would, however, take a systematic extension of the theory to make it speak to questions of health policy.

None of this need be taken as criticism of Rawls. Quite the contrary: if justification is a matter of continually trying to make our views more 
coherent, Rawls can agree that his theory needs elaboration in these domains, as indeed he has (Rawls 1982). But it does mean that it would be a mistake to come to Rawls seeking ready solutions for the dilemmas of health policy. As it stands now, his theory speaks far more articulately to economic inequality than it does to health policy.

Nozick's (1974) theory, however, does seem to offer more dispositive advice on health care. (Charles Fried [1975, 1976] has offered some Nozickian analyses of health care'issues, a subject on which Nozick is rather quiet-though see pp. 233-35. Still, Fried's inarticulate support of a socially guaranteed "decent minimum" is more than Nozick could grant.) Nozick insists on the primacy of property rights. If, he claims, one has attained what one owns by voluntary transactions, then one acts within one's rights in doing with it whatever one sees fit, as long as one harms no one else. The state acts legitimately only when protecting each individual's rights. If the state moves past protecting individuals from being harmed by others and it decides to redistribute property in order to make the lives of the poor more dignified, then, insists Nozick, the state trespasses on our rights and acts illegitimately. It might be nice for rich people to choose to support poor people, but we may not use the armed might of the state to compel them to do it. The import of this view for health care is clear enough: if you want to buy health care and you can afford it, you are free to do so. But no one has any claim on providers or rich people to force them to provide care for the poor. Our most minimal government programs for supporting health care would thus, in Nozick's view, be illegitimate. Nozick would surely want to add that so, too, would be the AMA's legislatively created monopoly and all the concomitant meddling in the market, and I assume that he would be sympathetic to Milton Friedman's suggestion that it is such interventionist legislation that drives up the cost of health care in the first place (Friedman 1962, pp. 149-60).

Here is guidance, to be sure, but it all hangs on the primacy of property rights. On that subject, Nozick has remarkably little to say. $\mathrm{He}$ has an easy time reminding us that we think people generally should be left alone to do what they like with what is theirs; powerful strands of our moral intuitions support the claim. And he develops a marvelous battery of arguments against any more interventionist state. But to cast the social welfare state as illegitimate, Nozick needs more than that reminder, more than his objections. His own view faces a pressing objection he is oddly silent about: he needs to assemble a case that property rights are so important that they outweigh the value of human life, if the two conflict. Yet he offers only cursory comments (Nozick 1974, pp. 30-35; 1981, pp. 498-504) on why we should take property rights so seriously 
and he, himself, acknowledges that his case for property rights is sketchy. (See Nagel [1981] for a heated critique of Nozick on these issues.)

Reading Nozick often elicits the intuition that health care just does not feel like another commodity to be bought and sold on the market, on a par with ballpoint pens or cruises through the Mediterranean. This intuition shows up in rueful comments from practitioners: "As one president of a county medical society said at an AMA meeting soon after Reagan took office, 'Our mentor has always been Hippocrates, not Adam Smith" " (Starr 1982, p. 419). We can take the relevant portion of Walzer's (1983) theory of justice as an attempt to work up this view in a theoretically sophisticated way. Walzer is skeptical of the attempt to work out general principles of justice. If we want to know how some social good ought to be allocated, he would urge, we need to interpret the reigning social meaning of that good. It will tum out that different goods ought to be allocated in different ways for different reasons.

Some goods, Walzer argues, have meanings that place their rightful distribution prior to the market. Human beings, votes, criminal justice, the Pulitzer prize, love and friendship, and more: these things, given our understanding of them, ought never be bought or sold. There is obviously no proscription in our society on buying and selling medical care, Walzer agrees. But the meaning of medical care, for us, is that it should go to those who need it. And once we see the implications of that principle of need, Walzer urges, we will "see no reason to respect the doctor's market freedom. Needed goods are not commodities" (Walzer 1983, p. 90). It is simply up to us, in democratic politics, to decide how much health care should be left to the market.

What guidance do we find here? Walzer is concerned by the oddly abstract quality of theories like that of Rawls. "My argument is radically particularist. I don't claim to have achieved any great distance from the social world in which I live" (Walzer 1983, p. xiv). Yet that particularism does not issue, indeed could not issue, some detailed legislative agenda in the form of a concrete blueprint. Our understanding of health care makes us uncomfortable with allocating it solely on the market. But when we think of health care, we obviously do not think of specific amendments to Medicare or Medicaid, and we do not instantly know whether we should more generously fund routine preventive care for the elderly. Those are the issues of which democratic debate is made. Walzer can remind us of the relevant general considerations that play into the debate, but speaking as an interpreter of our social world he can hardly pretend to have found the detailed agenda we have already implicitly adopted. There is no such agenda.

We are left with a discomfiting result. Nozick's theory does seem 
to offer guidance, but we have no good reasons to adopt the theory. And however sympathetic we are with Rawls or Walzer, it is not obvious what the implications of their views are. It is a mistake to come to general theories of justice, even ones as "particularist" as Walzer's, seeking specific guidance on policy issues. The policy-minded will then wonder what the point is of general theories of justice, especially if they attempt to articulate what an ideally just society is. We do not live in an ideally just society, and we are not going to live in one soon. And it would be too easy to say that ideal justice guides us by telling us what we should move toward. A libertarian might think an ideally just society would have neither social welfare nor interventionist regulation, but would refuse to support the abolition of social welfare now. Even though that would apparently be a step toward justice, he or she might think, existing interventionist legislation creates rampant unemployment and suffering that welfare programs ameliorate. The conclusion might be that we are better off with both than with only one. Such considerations of offsetting problems make ideal justice a problematic guide.

Having two separate literatures, one on justice and one on health care, is not going to help anyone. We need to learn to think theoretically about more concrete issues of health policy, "to develop better philosophical equipment to address questions in a nonideal world not always bent on basic reform" (Daniels 1985, p. 229; Daniels notes, "that effort was not my intention here"). For the remainder of this article, I shall try to sketch what such equipment might look like.

\section{LEARNING TO RELISH MORAL CONFLICTS}

Return for a moment to our moral intuitions. It is complacent to enshrine them as they stand; we need a way to criticize them. Escaping them completely, though, has proved decidedly unpromising. We need a way of drawing on them that makes it possible to question and revise them. How can we do that? In this section, I explain what one can do with moral conflicts; in the next, I turn to exploiting descriptive considerations.

Political theorists who set out to support some view by appealing to our intuitions will almost always have an easy time of it. Unless their views are unbelievably eccentric, our moral consciousness will have the resources they need. For, like it or not, our moral consciousness is remarkably capacious: we hold an embarrassing wealth of moral and political judgments and can easily see both sides of many, many issues. So one political theorist setting out to make a case for treating medicine as 
a commodity, to be bought and sold on the market, can remind us of our commitments to free choice and private property. He or she can forge those commitments into some imposing general principle, and then use that principle to attack antimarket views. At the same time, another political theorist setting out to make a case against treating medicine as a commodity can remind us of our commitments to satisfying need and supplying everyone with at least a "decent minimum". He or she can forge those commitments into an equally imposing but quite different general principle, and then use that principle to attack market views. Both arguments will seem striking; neither could be ultimately persuasive.

The same point could be made about reading our culture, or turning to the time-honored verities of American political thought. Our culture and our history are themselves profoundly ambiguous and ambivalent on all sorts of moral and political questions. So consider two accounts of what constitutes America's vaunted liberalism.

The first account: America was founded with a strong commitment to the essentials of John Locke's liberalism-private property, a state limited to protecting individual rights, religious toleration, and so on. States being the greedy creatures they are, though, American government began slowly but surely to grow, a growth that took off like some malignant cancer with the New Deal. The social welfare state is a renunciation of our liberal heritage, a step down Hayek's road to serfdom. Or it is simply a con game. In a brilliant indictment of the American welfare statewritten in 1883! - William Graham Sumner played an individualistic dissolving game with the rhetoric of welfare. What really goes on in social welfare programs, he claimed, is that $A$ and $B$ force $C$ to give money to $D$. And who could say they had the right to force $C$ along? Some who continue to hold to Lockean politics bitterly claim that the "liberals" of twentieth-century America simply stole the label, since it was so prestigious.

The second account: Liberalism has always been premised on a concern for the security and welfare of ordinary men and women. Liberals defended the limited state and private property when the major threats to ordinary people were absolutist rulers, tax farming, onerous apprenticeships, and the like. Once those threats faded, liberals properly turned their attention to new problems. Many decided that the market, once the promise of ordinary people, had become a new locus of uncontrolled power that left many helpless. The American welfare state, then, was not the renunciation of liberalism; it was its continued pursuit. So Edward Bellamy, defending socialism in the name of traditional American values, insisted that he represented "the true conservative party", fighting against the new and insidious "money power". Democratic socialism, in 
this view, is as American as apple pie. And it is no accident that as great a liberal as John Stuart Mill was also a democrat, a feminist, and at least deeply sympathetic with socialism.

Whether we turn to our intuitions or our traditions, then, we can make almost any proposal look good. To give one last example, from the recent debate about justice: It is too easy to make claims of desert and talent evaporate with a quick reference to the arbitrariness of the natural lottery, and it is too easy to mock claims of need by reminding us of property rights. So the procedure of forging one's favorite intuitions into a general principle, and then either ignoring other intuitions or assaulting them with the principle, is manifestly unsatisfactory. The same game can always be played by one's opponents. Much of the literature of contemporary political theory and public policy, I suggest, is flawed by a failure to recognize just how ambivalent and pliable our intuitions and history are.

We need to begin by focusing our attention on moral conflicts, instead of ignoring them or doing short shrift to either side of them. Focusing on such conflicts, thinking about why we have commitments to both sides and how we might plausibly transcend or resolve the conflicts would allow us to use our intuitions without enshrining them as sacrosanct. Consider a sampling - the list is anything but exhaustive-of conflicts arising in health policy. In every one of these cases, we do in fact have strong and contradictory commitments.

\section{SCIENCE AND TECHNOLOGY}

The scientific community thrives on a principle of free inquiry. Researchers, we think, should be allowed to do what they want to do. Granting them that freedom ensures the continued progress of science, and it is quite easy to summon up visions of Lysenkoism as the alternative. But we do not want science-happy doctors to play with whatever fancy new technology they can get their hands on. We do not want patients to be used as guinea pigs. And we worry that the uncontrolled deployment of new technology will send medical costs skyrocketing, and take away funds that could be used less dramatically but more effectively elsewhere.

\section{ATTENTION GETTERS AND THE ANONYMOUS}

The local news media find some wonderfully needy case-a frecklefaced eight-year-old needing massive transfusions and organ transplants after an accident-and make it a public cause. Donations flood in. Many 
other equally needy cases go unrewarded, because they happened not to be broadcast into thousands of homes. It is morally commendable to respond to people in need. But it is unfair to give disproportionate benefits to some because they happen to be better known.

\section{THE VALUE OF HUMAN LIFE}

Human life, we think, is priceless: In Kant's famous words, the dignity of man is of absolute worth, unlike any mere market value. Kant's transcendentalism aside, we have good historical reasons for insisting on this claim. We have rejected various social schemes-ancient criminal codes, slavery, mandatory dowries - that put an explicit price on human life. And we rightly take our rejection as notable progress. Yet social scientists and budget directors tell us ever more about the value of human life. We know that if we spend $x$ dollars more per year on highway safety, $y$ fewer people will die. We know to a niggling degree of precision just what it costs to keep a terminal patient alive with heroic therapies for another week. In fact, despite our aversions to facing the fact, human life does have a price. But how can we decide what price is worth paying?

\section{MEDICAL AUTONOMY AND MEDICAL NEED}

Part of the freedom of modern individuals is occupational choice: People, we think, should be allowed to choose their careers, not inherit them or be assigned to them. They should be allowed to decide for whom they will work and for whom they will not. But giving doctors such market freedom may mean leaving the needy drastically underserved. And the needy are just that: people in need of medical care. Such dramatic needs, we also think, ought to be satisfied. Once again, it would be too easy either to brand national health service as slavery, or to say with Walzer that we see no reason to respect the doctor's market freedom. We see reasons to respect it and reasons not to.

\section{EQUALITY OF OPPORTUNITY AND CONSUMER CHOICE}

Health care seems not to be an ordinary commodity; many are tempted by some principle of equality of opportunity to account for its proper distribution. But how much of its distribution? Should the rich be entitled to purchase cosmetic plastic surgery? Or face-lifts? Or should such medical care be placed outside the realm of the market? The more scope we assign to equality here, the more we limit consumer choice. And we do value consumer choice. Adding a time dimension only ag- 
gravates the dilemma. If it is true here too that market freedom tends to promote innovation and progress, today's market medicine may provide tomorrow's therapy for all. If there is a conflict between the interests of the present poor and the future poor, how should it be resolved? (I owe the core form of this puzzle to Amy Gutmann [1983].)

\section{PATIENT AUTONOMY AND PATERNALISM}

Patients are human beings like the rest of us. They want to know what their prognosis is, what the risks of the relevant procedures are, even and notoriously whether they will ever play the piano again. We recognize their autonomy partly by giving them answers to these questions. Yet there are better reasons than the convenience of doctors not to answer these questions all the time. We may think that leaving a patient in blissful ignorance will increase his or her chances of recovery. Here is a case for treating patients paternalistically. Like other such cases, it is one we recognize reluctantly.

\section{INDIVIDUAL RIGHTS AND SURVEILLANCE}

In a world of electronic data banks, we insist on privacy as a crucial individual right. People should be left alone to pursue their own plans as they see fit, without worrying about snoopy state functionaries bugging them. Yet in the name of protecting individual rights-the rights of deformed infants - the Reagan administration established alarmingly intrusive procedures, complete with a 24-hour hot line to let anonymous tipsters turn in doctors who were assisting parents in making heartbreaking decisions. The Reagan scheme might be defended as the only plausible way to prevent genteel, antiseptic murder.

\section{FREEDOM OF CHOICE AND LIFE}

We are committed to both life and free choice: Life, liberty, and the pursuit of happiness is the canonical phrase for Americans. But life and liberty may conflict. If a lucid 60 -year-old drafts a living will saying he or she would like euthanasia if Alzheimer's disease or some other mentally disabling disorder develops, should we respect that will? (It hardly helps to suggest that we ask the person after the disease has been contracted whether he or she still wants to be so bound. The person's later self, unlike the earlier self, is incompetent-and that is just what the person feared.) The law is ambivalent on the question, and so are we. Only the doctrinaire could fail to be tugged in both directions on this question. 


\section{INDIVIDUAL RESPONSIBILITY AND INDIVIDUAL SUFFERING}

Built into tort law and everyday notions of moral responsibility is a focus on villains. If you have been harmed, you should be able to point to the person or persons who did the harming. Crime with villains is easy to see, so it is no wonder we have riveted our attention on it. Yet we now know there may be crime without villains. Corporations in good faith may dump what everyone thought were harmless chemicals, and freakish chemical reactions may create toxic chemicals leading to birth defects. Individuals may end up suffering without being able to show who has harmed them. Workers suffering asbestosis know very well why they have it, but if they worked in three different plants over 30 years they will find it impossible to demonstrate which employer harmed them. If we insist on individual responsibility, we do not compensate the suffering. If we insist on compensating the suffering, we qualify individual responsibility.

\section{THEOLOGY AND SCIENCE}

Liberal societies guarantee freedom of religion, partly by tying such freedom to a separation of church and state. Science is another separate institution in liberal society. In the laboratory, no one should care what your religion is; in church, your salvation should not depend on your views on quantum mechanics. But such separations are never hard and fast, and religion and science have been coming to blows in heated issues of public policy. One such issue is relevant to health policy: When is a person dead? The scientific community may be increasingly fond of brain death, on the grounds that without a properly functioning central nervous system there is nothing that we can recognize as a person. But the theologically inclined may take this as another piece of secular blasphemy, and insist that as long as a heart is beating the soul has not yet departed. Which view should the state enforce? And why? Is it possible for the state here to be "fair" or "evenhanded" or "neutral"?

\section{FERTILE EGGS AND FUTURE SELVES}

Suppose a scientist wants to experiment on fertile eggs and takes extra eggs and sperm donated for other purposes to create the fertile eggs. Suppose the point of the experiment is to find out more about the genetic bases of various birth defects. That research would, if successful, pay off in the welfare of the yet unborn. May we use fertile eggs this way? The fuss raised in England over this question suggests that it is not an easy 
one. We are not sure what rights if any to ascribe to blastulas and the like, nor are we sure what standing future generations have. And then there is the additional issue of using some for the welfare of others. One can arrive at an easy enough judgment here if one is so inclined. One can say that fertile eggs are persons and persons can never be used. Or one can say that fertile eggs are fertile eggs, open to any laboratory use we like. Either answer involves ignoring some of our intuitions. The puzzle is reminiscent of the much older debate on the defensibility of vivisection, now heated up again with the animal rights campaign and accusations of speciesism. Animals, fertile eggs, the badly deformed, and the unborn: all challenge us to refine our rather inchoate picture of what beings are entitled to what sort of moral regard.

\section{STRATEGIES FOR HANDLING CONFLICTS}

If we begin by forcing ourselves to give these conflicts their due, we can have more confidence in our arguments. We need not worry that we have made things too easy on ourselves by discussing only those intuitions that lead us to our desired conclusion. Once the conflict is on the table, we do not have to throw up our hands and confess that we are morally and politically paralyzed. There may be such moral and political dead ends, but there are also strategies for resolving conflicts. Consider some schematic possibilities.

We might decide to demarcate the boundaries within which our various commitments should apply. For instance, one plausible reaction to the putative conflict between free scientific inquiry and untrammeled deployment of new medical technology might be to articulate a line between basic and applied research. We might argue that scientists carrying out basic research, in laboratories or teaching hospitals, should be left to their own devices. But doctors, who are basically in the business of serving patients, must submit to institutional constraints justified in turn by the goal of serving patients. Similarly, we might decide that while ordinarily we have good reasons to respect individual autonomy, helpless patients fall into a different context in which paternalism may be justified. These moves, of course, are only the bare beginnings of real arguments and I do not mean to endorse them. I want only to show how demarcation might work as one way of handling conflicts.

Instead of demarcating the scope of the principles, thus ensuring there is no context in which they both apply, we might adopt some priority rule. Rawls's principles of justice include a number of such rules: the priority of liberty means that we may never sacrifice liberty for economic advantage; the just savings principle means that we may never help to- 
day's poor if it means systematically disadvantaging future generations. Here we might say that individual responsibility is all well and good, but not if it means that those who suffer through no fault of their own are left uncompensated. So we might assign priority to rewarding the victims of asbestosis and say that here individual responsibility must give way. Our priority rules need not be lexical, as Rawls's are; they need not say, that is, pay no attention to the second until you have satisfied the first. And obviously there are plenty of structural possibilities for weighing conflicting commitments.

Both these strategies assume that we retain a commitment to both intuitions that create the conflict. There are also strategies for revising or even scrapping one (or both!) intuitions that create the puzzle. I will mention two ways of drawing on our intuitions without taking them as ultimately decisive.

We might ask for a reason supporting some judgment. Asking why over and over again can make us sound like philosophical skeptics, or stubborn five-year-olds-and the two have resemblances worth exploring. But that hardly means that we should never ask why. It may turn out that some judgments are stupendously difficult to support. For instance, patrons of a theological conception of death may find it very hard to mount a coherent argument for having the state enshrine their views into law.

More intriguing is that we can use the history of our moral and political intuitions as a critical tool. Understanding how we came to cling to some judgments may transform a stubborn intuition into a more nuanced judgment, or it may even make us decide that the judgment no longer applies. I began to sketch such an argument earlier when commenting on why we insist that human life is priceless. Once we see the place that judgment had in rejecting institutions like chattel slavery, the road is clear for us to explain what is different about deathbed settings. Here, we might say, there is no issue of treating people as property. Here, others might rejoin, there is all too pressing an issue of abusing some people for the sake of others-weary family members, or overtaxed insurers. Moral and political intuitions have their homes, their explanatory and justificatory homes, in certain social settings. Investigating those settings can help us to criticize and revise the intuitions. Gary Hart has alerted us to the need to beware the failed policies of the past. More worrisome are the successful policies of the past, which may well have outlived their usefulness. Our intuitions will lag dreamily on, endorsing positions and practices which have become bankrupt. As a result, policymakers, like generals, may always be fighting the last war.

This last line of argument, I believe, could be enormously powerful 
in thinking about health care. It leads me to the second general strategy I mentioned for criticizing intuitions: making facts criticize our values.

\section{FACTS AGAINST VALUES: CRITICIZING THE MARKET MODEL}

That facts might be able to criticize values is a puzzling notion. Using the best philosophy of science now available, facts cannot even serve as critical tests that descriptive theories must pass. How then can they be used against avowedly evaluative views? I readily grant that a factual proposition cannot logically contradict an evaluative one. That logical point, though, settles nothing.

The fact-value gap has seemed alluring to many, and not just as a logical schism. Social scientists routinely use it to explain why they do not have to care about evaluative questions, while moral and political theorists routinely use it to explain why they do not have to care about factual questions. Both sides seem worse off when making that move, especially when it comes to thinking about public policy. Policy positions are always mixtures of "facts" and "values", caught up together in a complex web. It is a rare political proposition that is either purely factual (the president of France is elected for a seven-year term) or purely evaluative (Nixon is awful). Most are mixed (Stockman rudely assaulted the nation's farmers), and nothing would be gained for most purposes by trying to sort them out into their logically separable factual and evaluative components.

Policy analysts, implicitly or explicitly, summon up pictures of what the world is like, both in criticizing other views and in advancing their own. The plausibility and even intelligibility of their views depends partly on the accuracy of those depictions. A simple example will help make the point. Recall a common complaint about social welfare programs: by rewarding people for being lazy, we encourage them to be lazy. Or, as Auberon Herbert once put it, a country can have exactly as many paupers as it chooses to pay for. This complaint is often tied to a similar view: recipients of social welfare do not really need it; they could get a job and support themselves, but they would rather loll around on the dole. If someone is making this sort of complaint to argue against Medicaid, facts can play an explosive role. He or she may be surprised to hear that most poor people are children. That inconvenient fact makes it impossible to go on voicing the common complaint about social welfare recipients. Children have not chosen their parents, do not choose to be poor, and 
could not go out and earn their keep if the government withdrew its support.

Max Weber suggested that it is the professional obligation of social scientists to produce such inconvenient facts, indeed to produce facts that embarrass all partisan points of view. We can advance the point in a way Weber would have found perfectly congenial. Not just individual facts, but whole theories of the way the world works, may be wrong in ways that make nonsense of certain policy positions. This possibility offers the critical strategy that Cervantes executes so brilliantly in Don Quixote. The poor Knight of the Sorrowful Countenance sets out with a vision of chivalry that demands damsels in distress, villains, and the like. But those figures appear nowhere in his social world, so his quest is doomed to failure-even if he perseveres in seeing garlic-stinking Dulcinea as a damsel. So some projects, including some policy positions, may be quixotic.

I want now to sketch an argument of this sort against what I shall call the market model of medical services. I choose that model not, surely, because it is the only one around open to fundamental criticism, but because it happens to command a great deal of public rhetoric and the political agenda right now, in ways that strike me as pernicious.

A pure market model might run this way: Health care is another commodity to be bought and sold by freely consenting adults in an open market. Some individuals get sick, some do not; some individuals sell health care, some do not. Individual practitioners put their services up for sale; consumers can buy or sell as they see fit; good practitioners will be rewarded, bad ones penalized. Government meddling in this market is an intrusion on the market liberties of patients and doctors alike. In its pure form, this view commands the allegiance of a relatively small group of libertarians. But impure forms of the same model are much more common. Someone may add that we need to ensure a "decent minimum", or that consumers may not be as rational as their neoclassical economic portrait suggests. Basically, however, the market model still drives the analysis-not just the bare factual claims, but the policy arguments about what is worth doing and what is not. We are all familiar with the contrast between smoothly humming markets and tiresomely inefficient bureaucracies.

The market model is wrong, though. It is a bad depiction of the world, both the world as it exists and any imaginable alternatives we now face. As a result, the market model leads to skewed policy formulations, formulations that can be criticized effectively by undercutting the descriptive plausibility of the model. We can discern no fewer than seven points of strain, seven ways in which the market model misdescribes the world. 
I have already noted the first. To call something a commodity is to say that we think of it as something to be freely bought and sold, and we attach no moral significance to the decisions people make about whether and when to buy and sell it. That something is properly seen as a commodity can always be questioned: Marx sets out to indict political economists for casting labor as just another commodity, and worries that the rest of us share that distorted view. But no such ambitious critique is needed here. As a matter of fact, we do not think of health care as just another commodity, which is the sort of observation a detached moral anthropologist might report after observing our society. Instead, we think it raises issues of need and justice. The market model thus misdescribes the deeply held views we have of just what sort of thing health care is. (Daniels [1985, chapter 2] and Walzer [1983, pp. 86-91] both attempt to explain how health care is special. Daniels wants to link health care needs to normal species functioning, Walzer to a sphere of communal provision, but both authors decisively reject the market model.)

Second, the medical market, as Kenneth Arrow (1963) has argued, is an anomalous market indeed, one destined to curious market failures. For instance, there is enormously lopsided knowledge. The "consumer" knows or suspects that something is wrong with him. The doctor tells the patient what that is and what ought to be done about it. The patient, however, is in no position to judge the merits of the diagnosis or prognosis, and may well feel that getting a second opinion increases his helplessness. Bernard Shaw mordantly noted the implications: "That any sane nation, having observed that you could provide for the supply of bread by giving bakers a pecuniary interest in baking for you, should go on to give a surgeon a pecuniary interest in cutting off your leg, is enough to make one despair of political humanity" (Shaw 1975, vol. 3, p. 226).

Shaw's point is not of course that all doctors are fiends, or that all disease is iatrogenic, even if some left-wing critics of modern medicine talk that way. (For example, see Illich 1976.) Rather, the point is that the medical market has what game theorists might call a strategic structure, which makes it a game of mixed conflict and cooperation with great uncertainty. This third point underlines the significance of the asymmetry of knowledge in the medical market. We find the expected putative solutions to the troubling problems raised by Shaw's point. So the Hippocratic oath could be taken as an attempt to establish a norm in the medical community that precludes doctors from generating a demand for their own services. And the viability of malpractice suits can be taken as a sanction ensuring compliance to the norm. Ironically, though, the extraordinary sums of cash routinely awarded in malpractice suits, even if deserved, have driven up malpractice insurance premiums so high that that 
expense creates a new incentive to find disease where it may not existand, less dramatically but more ordinarily, to do all sorts of testing as a precaution.

Once we note the key role incentives play in structuring the rational behavior of doctors and patients, we may be tempted to juggle the incentives to improve matters. So Shaw, complacently fond of the state as ever, was sure that socializing medicine would give physicians incentives to keep people healthy. Our more recent fascination with vouchers and Health Maintenance Organizations is very much in the same line, however different it is politically. Here we find an epicycle on the market model: If the world does not run the way economic theory says it should, let us restructure the world so that it does. I assume that is the source of the appeal of Alain Enthoven's voucher plan (Enthoven 1980a, b), or the abortive federal drive of the 1970s to promote HMOs. Many things might be said about the viability of this strategy, but the bottom line seems clear: this is a case of many a slip 'twixt cup and lip. HMOs are supposed to create incentives to keep people healthy, but they also create incentives to underserve the needy and drive out the chronically ill. In the 1970 s according to Lawrence Brown (1983, pp. 139-40), "In certain California plans, set up mainly to serve Medicaid recipients, officials attempted to do just that, by refusing to answer emergency room phones, keeping patients waiting for appointments until they gave up and went to local hospitals' outpatient or emergency departments (which the plan then refused to reimburse), by administering tranquilizers to make patients feel better in spite of physical problems, and by several other infamous expedients." (Brown's study might be taken. as a model of showing how certain policy analyses offer distorted accounts of the world, and fail as policy as a result.)

The fourth point follows naturally from thinking about strategic interaction and asymmetric knowledge. Though the market model does not mention it, relations between doctors and patients are inevitably power relations. Again, authority in this context is here to stay and seems justifiable. But it sharply distinguishes health care from ordinary market transactions, officially between free and equal agents. Just as Adam Smith and Karl Marx both argued that it is implausible to view the labor màrket as featuring voluntary transactions, since workers have no choice but to work and cannot outlast their wealthy employers in a showdown, so it is implausible to view a transaction between doctor and patient as simply a voluntary transaction between free and equal agents. Paul Starr has insisted on the institutional implications of what he calls professional sovereignty; the point is equally decisive in thinking about interactions between individual doctors and patients. Michel Foucault has offered a 
striking account of the exercise of power in clinical settings, where naked bodies are put under the dispassionate gaze of authorities (Foucault 1975; 1980, chapters 5-9). The account is overblown; nonetheless it is useful as a corrective to the market model.

The fifth point argues against the easy contrast between market productivity and the stifling dead hand of government regulation. If we do not insist on seeing the world through the lens provided by the model, we will notice that the government has played an enabling role in twentieth-century American health care. Hill-Burton and the National Institutes of Health undeniably have contributed to the development of the American health care industry. Underlying the market model here is a misleading account of power and market. An unfortunate linchpin of liberal social theory, from Bentham to Tocqueville, Hayek to Nozick, is the view that rules (and so laws) limit our options. Some rules, though, function as do the rules of grammar: following them enlarges our options. No one can intelligibly complain that following the rules of grammar limits one's options by preventing one from uttering prepatterned noises; speaking language vastly multiplies our options. Similarly, some health legislation has multiplied the options of practitioners and patients alike.

The sixth point is a rejoinder to the individualistic focus of the market model. The model pictures individual consumer-patients shopping around, and individual doctors offering their services. But the practice of health care in twentieth-century America is increasingly corporate. Those demanding health care are firms and the government, who speak for enormous groups of patients. Those supplying it are hospitals, Kaiserstyle health plans, and the like. So instead of the market model's vast number of anonymous individuals, none of whom can significantly affect market conditions, a few huge players dominate the market. We are closer to monopoly and monopsony than we are to a perfectly competitive market.

The seventh and final point is the most crucial, if the most abstract, and again focuses on the individualism of the market model. In the model, some people happen to get sick, others do not. That sort of individualism has been a staple of American political thought for a long time: Not only have we Americans justly congratulated ourselves on not having the relatively immovable and visible class structure of European societies, we have foolishly flattered ourselves by thinking that we have no class structure at all. Yet that piece of folk wisdom is utterly dubious. We know that class, race, and ethnicity are tremendously important in the formation of life chances in America. Just as being born the son of J. Paul Getty increases one's chances of ending up wealthy, so being born in an innercity ghetto increases one's chances of contracting some diseases and decreases one's chances of getting help for them. The social distribution of 
health and disease, of therapy and neglect, makes a mockery of the market model's focus on solitary individuals who make their own choices. We do of course make choices, but always against a background defined by sociological factors that we have not chosen at all. Just as the explanatory (pseudo?) question, "Why is there no socialism in America?" has tantalized generations of labor historians, so the question, "Why is there no national health insurance or national health service in America?" engages some working in health policy. The answer simply cannot be American distrust of the state. Historically, that distrust has coexisted quite peacefully with almost boundless faith in the state, at least in some junctures. The deeper and more interesting answer, I suggest, lies in our intuitive methodological individualism. That individualism makes it easier to cast socialized health services of any form as a bizarre intrusion in the dealings of free individuals.

That health care is needed, that it is dispensed by doctors with superior shares of knowledge and power in settings marked by quirky incentives, that government intrusion may increase human choice, that the medical market is dominated by corporate actors, that disease is socially distributed: all these factors argue against the market model's descriptive plausibility. Insofar as they do that, they make policy recommendations based on the market model suspect. Nothing I have said here precludes the possibility that markets are still a better way of providing health care than a national health service or other alternatives. But given the considerable gaps between the world pictured by the market and the real world, any responsible case for the market will have to be tentative. The only way to be fully enthusiastic about a market in health care is to mistake the market model for reality. We need models, of course, if we are to understand the world at all. But we do not need to cling to oversimplified models that do ideological work. Today's champions of the, market in health care are valiant but pathetic Quixotes, tilting at windmills. At the moment, they seem not to have even a Sancho Panza to look after them. Worse yet, they happen to be in charge.

\section{CONFLICTS, MUDDLES, AND THE WORLD OF POLICY DEBATE}

I have been endorsing ambiguity and conflict, and skeptically assaulting drives to enshrine shining principles for what should happen, or simple theories of what does. Some may indignantly respond that this is a rationale for leaving ourselves hopelessly muddled, and that surely the point of theory is to illuminate the world. My response, predictably, 
would run this way: there are muddles and muddles, some inarticulate and confused, some nuanced and precise. If anything is to be made of policy as the science of muddling through, we need to replace our baffled and inarticulate muddles - and our neatly precise but false accountswith more precise and accurate ones. If we want to learn how "to strive for imperfection" (Gutmann 1983, p. 66), we need to confront moral conflicts and to correct our images of how the world works. Finding a reasonable health policy, if there is one, will depend on getting our "values" and "facts" straighter than they now are.

\section{REFERENCES}

Arrow, K. J. (1963). "Uncertainty and the Welfare Economics of Medical Care," American Economic Review 53 (December): 941-73.

Brown, L. D. (1983). Politics and Health Care Organization. Washington, D.C.: Brookings Institution.

Daniels, N. (1985). Just Health Care. Cambridge: Cambridge University Press.

Enthoven, A. (1980a). Health Plan. Reading, Mass.: Addison-Wesley. (1980b). "How Interested Groups Have Responded to a Proposal for Economic Competition in Health Services," American Economic Review 70 (May): $142-48$.

Foucault, M. (1975). The Birth of the Clinic, trans. A. M. S. Smith. New York: Vintage Books.

. (1980). Power/Knowledge, ed. C. Gordon. New York: Pantheon.

Fried, C. (1975). "Rights and Health Care," New England J. of Medicine 293 (July 31): $241-45$.

(1976). "Equality and Rights in Medical Care," Hastings Center Report 6 (February): 29-34.

Friedman, M. (1962). Capitalism and Freedom. Chicago: University of Chicago Press.

Gutmann, A. (1983). "For and Against Equal Access to Health Care." In In Search of Equity, eds. R. Bayer, A. L. Caplan, and N. Daniels, 43-67. New York: Plenum Press.

Hare, R. M. (1975). "Abortion and the Golden Rule," Philosophy \& Public Affairs 4 (Spring): 201:

Harvard University, Institute for the Study of Smoking Behavior and Policy (1985). "Burning Holes in the Budget," The Economist 296 (September 20): 32.

Herzog, D. (1985). Without Foundations. Ithaca, N.Y.: Cornell University Press. Illich, I. (1976). Limits to Medicine. London: Marion Boyars.

Mackie, J. L. (1977). Ethics. Harmondsworth: Penguin.

Nagel, T. (1981). "Libertarianism without Foundations." In Reading Nozick, ed. J. Paul, 191-205. Totowa, N.J.: Rowman \& Littlefield.

Nozick, R. (1974). Anarchy, State, and Utopia. New York: Basic Books. (1981). Philosophical Explanations. Cambridge: Belknap Press, Harvard University Press. 
Prichard, H. A. (1971). Moral Obligation. Oxford: Clarendon.

Rawls, J. (1971). A Theory of Justice. Cambridge: Belknap Press, Harvard University Press.

(1982). "Social Unity and the Primary Goods." In Utilitarianism and Beyond, eds. A. K. Sen and B. Williams, 159-85. Cambridge: Cambridge University Press.

Ross, W. D. (1973). The Right and the Good. Oxford: Clarendon.

Shaw, G. B. (1975). The Doctor's Dilemma, preface. In Collected Plays with Their Prefaces. 7 vols. New York: Dodd, Mead.

Starr, P. (1982). The Social Transformation of American Medicine. New York: Basic Books.

Thomson, J. J. (1971). "A Defense of Abortion," Philosophy \& Public Affairs 1 (Fall): $47-66$.

Walzer, M. (1983). Spheres of Justice. New York: Basic Books.

Wolff, R. P. (1977). Understanding Rawuls. Princeton: Princeton University Press. 